\title{
Türkiye'de Yapılan Lisansüstü Tezlerin Okul Öncesi Dönem Çocuklarının Gelişimlerine Etkisi: Bir Meta Analiz Çalışması*
}

\author{
Investigation of Thesis Supporting the Developmental Fields of the \\ Preschool Children Conducted in Turkey: A Meta-Analysis Study
}

Osman Basit, Ümit Deniz

\begin{tabular}{l} 
Yazar Bilgileri \\
\hline Osman Basit \\
Arş. Gör. Dr., Adıyaman \\
Üniversitesi Eğitim \\
Fakültesi, Temel Eğitim, \\
Okul Öncesi Eğitimi, \\
osmanbasit@gmail.com \\
Ümit Deniz@ \\
Prof. Dr., Gazi \\
Üniversitesi, Gazi Eğitim \\
Fakültesi, Temel Eğitim, \\
Okul Öncesi Eğitimi, \\
sea edu2003@yahoo.com
\end{tabular}

ÖZ

Alanyazında farklı araştırmacılar tarafından, farklı örneklem gruplarıyla, farklı zamanlarda, farklı yerlerde yapılmış bireysel çalışmaları bir araya getirmek, o konudaki yapılan çalışmaların bütününü görmek açısından önemlidir. Bu araştırmanın amacı, Türkiye'de 1998-2020 yılları arasında yayımlanan, okul öncesi dönem çocuklarının gelişim alanlarını desteklemeye yönelik olarak yapılan lisansüstü tezlerdeki deneysel çalışmaların etkisini meta analiz yöntemiyle incelemektir. Bu amaç doğrultusunda ilgili yıllar içerisinde yapılan 250 lisansüstü tez araştırma kapsamına dâhil edilmiştir. Araştırma kapsamında ele alınan lisansüstü tezlerde uygulanan eğitimsel müdahale programlarının okul öncesi dönem çocuklarının gelişimlerine etkisi incelenmiştir. Araştırma sonucunda, gelişimi destekleyen 246 tezin büyük düzeyde $(\mathrm{d}=1,102)$ etkisinin olduğu tespit edilmiştir. Ayrıca araştırma kapsamına giren 250 tezden 37'sinde deney grubundaki çocuklara uygulanan müdahalelerin cinsiyete göre etkisi incelenmiştir. Cinsiyet değişkeni ile ilgili meta analiz sonucunda, eğitimsel müdahalelerin kız çocuklar ile erkek çocukların arasında gelişimsel farklılığa neden olmadığı belirlenmiştir. Moderatör analizine göre, uygulanan eğitimsel müdahalelerin toplam süresinin 10 hafta ve üzerinde olmasının, haftalık oturum sayısının üç gün ve üzerinde olmasının ve uygulama yapılan gruptaki çocuk sayısının 20'nin altında olmasının eğitimsel müdahalenin çocukların genel gelişimlerine etkisini artırdığı tespit edilmiştir.

\begin{abstract}
Makale Bilgileri
\section{ABSTRACT}

In literature, some studies were conducted independently of each other and revealed different results on a similar subject. It is essential to gather individual studies made by different researchers, with different sample groups, at different times and in different places, in order to see the whole of the studies on that subject. This study aims to examine the effect of experimental studies on postgraduate theses published between the years 1998-2020 in Turkey conducted to support the developmental areas of preschool children by meta-analysis method. For this purpose, 250 graduate theses made in the relevant years have been included in the research's scope. The effects of educational intervention programs applied in the postgraduate theses discussed within the study's scope on the development of preschool children were examined. As a result of the research, 246 theses supporting development have been found to affect at a large level $(d=1,102)$. Besides, in 37 of 250 theses within the research scope, the effects of the interventions applied to the children in the experimental group by gender were examined. As a result of the meta-analysis on the gender variable, it was determined that educational interventions did not cause developmental differences between girls and boys. According to the moderator analysis, it was determined that the total duration of the applied educational interventions was ten weeks or more, the number of weekly sessions was three days or more, and the number of children in the applied group was less than 20, which increased the effect of the educational intervention.

Makale Geçmişi
\end{abstract}

Geliş: 31.01.2021

Düzeltme: 10.03.2021

Kabul: 12.03.2021

* Bu çalışma, ikinci yazar danışmanlığında birinci yazar tarafından yürütülen doktora tezindeki verilerin bir kısmından üretilmiştir. 


\section{Giriş}

Okul öncesi yılları, insan hayatının bütün gelişim alanlarının temelini oluşturan bir dönemdir. Çocuğun doğduğu günden temel eğitime başladığı güne kadar geçen yılları kapsayan ve sonraki yaşamda önemli rol oynayan bedensel, motor, sosyal ve duygusal, zihinsel ve dil gelişimlerinin büyük ölçüde şekillendiği okul öncesi eğitim dönemi yaşamın temel taşlarını oluşturur (Milli Eğitim Bakanlığı [MEB], 2013). Bu dönemde çocuğa sağlanacak yaşantıların türü ve kalitesi, büyük oranda yetişkinin ona verebileceği olanakların niteliğine bağlıdır (Oktay, 2007).

İnsan yaşamına son derece önemli bir katkı sağlayan okul öncesi eğitimi ile ilgili Nobel ödüllü iktisatçı James Heckman (2012), erken çocukluk döneminde yapılan her bir dolarlık yatırımın uzun vadedeki toplumsal maliyet ve getirileri göz önünde bulundurarak yedi dolara kadar geri dönüş sağladığını ortaya koymaktadır. Çocuklara sunulan kaliteli eğitimin erken yaşlardan itibaren başlamasının, çocukların gelişim düzeylerine ve temel eğitime başlama olgunluğuna olumlu anlamda katkı sağladığı kabul gördüğünden gelişmiş ülkelerin birçoğu okul öncesi eğitim okullaşma oranını \%90'ın üzerine çıkarmışlardır (Organisation for Economic Co-operation and Development [OECD], 2016, 2017).

Okullaşma oranının yanında eğitime verilen önemin bir diğer göstergesi, okul öncesi eğitim alanında yapılan akademik çalışmalardır. Okul öncesi eğitimin önemini, çocuklar, ebeveynler, öğretmenler, eğitim yöneticileri gibi eğitimin bütün bileşenlerinin okul öncesi eğitime yönelik tutum ve beklentilerini ortaya koymak ve nitelikli erken çocukluk eğitiminden faydalanan çocuk sayısını artırmak için bütün dünyada olduğu gibi Türkiye'de de her gün artan sayıda akademik çalışmalar yapılmaktadır. Yapılan bilimsel çalışmalar kitap, makale, bildiri, tez vb. gibi çeşitlenmektedir. Söz konusu çalışmalar ebeveynler, çocuklar, öğretmenler, öğretmen adayları ya da akademisyenler gibi farklı gruplara yönelik olarak yürütüldüğü gibi deneysel, betimsel, ilişkisel, vaka analizi vb. gibi farklı modellerde gerçekleştirilmektedir. Farklı yöntemler kullanılarak gerçekleştirilen akademik çalışmalarda okul öncesi dönem çocuklarına yönelik olarak gelişimsel destek programları deneysel desende planlanmış lisansüstü tez çalışmaları olarak ya da projeler kapsamında yürütülmektedir. Fakat bu deneysel çalışmaların bütünsel olarak ele alındığı, verilen eğitimlerin gelişim alanlarına etkisine yönelik meta analiz çalışmalarına daha az rastlanılmaktadır.

YÖK Ulusal Tez Merkezi verilerine göre Türkiye'de sadece 2019 yılında 72.527 lisansüstü tez tamamlanmıştır. Araştırmanın çalışma grubu olarak ele alınan 1998 yılından ve 2020 yılının Mart ayına kadar geçen sürede 535.594 lisansüstü tez yazıldığı YÖK Ulusal Tez Merkezinin istatistikleri arasında yer almaktadır. Lisansüstü tezlerin konu alanlarına göre dağılımı incelendiğinde ise eğitim ve öğretim konu alanında 2020 yılının Nisan ayına kadar yazılan tez sayısı 51.074'tür ve bu sayı bütün 
konu alanları içerisindeki en yüksek lisansüstü tez sayısıdır. "Okul öncesi" anahtar kelimesi kullanılarak yapılan taramada 1998 ve 2020 yılları arasında tamamlanan tez sayısı 3.717' dir.

Yapılan bilimsel çalışma sayısı arttıkça kapsamlı ve sistematik araştırma sentezlerine olan ihtiyaç da artmaktadır. Ağırlıklı olarak sağlık bilimlerinde kullanılmış olsa da son yıllarda sosyal bilimler ve eğitim bilimleri alanında da kullanılan meta analiz en etkili araştırma sentezi yollarından biridir.

Meta analiz; yöntemleri ve sonuçları farklı, hatta birbirleriyle çelişen araştırmaların sayısal sonuçlarının birleştirilmesidir. Meta analiz araştırmacıların analize dâhil ettikleri çalışmaların hiçbirinden elde edemeyecekleri kadar net sonuçlar elde etmelerine olanak sağlar (Hunt, 1997). Borenstein, Hedges, Higgins ve Rothstein (2013) “Meta analiz; çalışma serilerindeki sonuçların istatistiksel olarak sentezlenmesi" şeklinde tanım yapmışlardır.

Okul öncesi eğitim alanında yapılan bilimsel çalışmalar incelendiğinde okul öncesi dönem çocuklarının gelişim alanları (bilişsel, psikomotor ve sosyal duygusal) ile ilgili bir meta analiz çalışmasına rastlanılmamıştır. Farklı örneklem grupları, yöntemleri, ölçme araçları ve modelleri kullanılarak yapılan, uzun bir sürece yayılan araştırmaların meta analiz ile ele alınması ve sonuçlarının bütünlük içinde sunulması, okul öncesi eğitim ve bu alanda yapılacak olan yeni çalışmaların kalitesine katkı sağlayabileceği gibi çocukların gelişimsel olarak desteklenmelerinde de daha net bilgiler sunabileceği düşünülmektedir.

Türkiye'de okul öncesi eğitim alanında meta analiz çalışması yok denecek kadar azdır. Okul öncesi eğitim konusunda yapılan çalışmaların incelendiği çalışmalar sistematik derleme şeklindedir (Ahi ve Kıldan, 2013; Altun, Şendil ve Şahin, 2011; Avar ve Ilıcan, 2018; Bertan, Haznedaroğlu, Koln, Yurdakök ve Güçiz, 2009; Can-Yaşar ve Aral, 2011; Ertürk-Kara ve Aydın-Şengül, 2016; Günindi, Aydın, Ertürk-Kara ve Koruk, 2018; Öncül, 2014; Taştepe, Öztürk-Serter, Yurdakul, Taygur-Altıntaş ve Bütün-Ayhan, 2016; Yılmaz, 2018). Meta analiz incelemesi yapılan çalışmalar ise diğer eğitim kademelerinden çalışmaları da içermekte okul öncesi dönem çocuklarının yer aldığı çalışmalar son derece sınırlı sayıda kalmaktadır (Gözüyeşil ve Dikici, 2014; Rafe, 2006; Turgut ve Doğan-Temur, 2017). Fakat yurt dışında özellikle de Amerika Birleşik Devletleri'nde meta analiz çalışması olarak yapılmış çok sayıda yüksek lisans ve doktora tezi ve makale bulunmaktadır (Alvarez-Bueno vd., 2017; Alvarez-Bueno vd. 2020; Corcoran, O'Flaherty, Xie ve Cheung, 2020; De Greeff, Bosker, Oosterlaan, Visscher ve Hartman, 2018; Elliott, Patricia, Shauna ve Albert, 2013; Engel, Broderic, van Doorn, Hardy ve Parmenter, 2018; Fukking, Jiling ve Oostdam, 2017; Johnstone, Hughes, Martin ve Reilley, 2018; Kasser, 2016; Kennedy, 2010; Kim, 2018; Kwon, Lee ve Lee, 2016; Murano, 2019; Nelson ve McMaster, 2019; Schimmel, 2018; Utesch, Bardid, Büsch ve Strauss, 2019; Van Capelle, Broderick, van Doorn, Ward ve Parmenter, 2017; Vazou, Pesce, Lakes ve Smiley-Oyen, 2019; Wick vd., 2017; Zeng 
vd., 2017). Araştırma sayesinde Türkiye'deki okul öncesi eğitim alanının son 22 yılının bir nevi sentezinin yapıldığı söylenebilir. Araştırmayla son 22 yılda deneysel desende tasarlanmış lisansüstü tezlerde uygulanan eğitimlerin okul öncesi dönem çocuklarının bilişsel, psikomotor ve sosyal duygusal gelişim alanlarına ve gelişimine etkisi incelenmiştir.

Türkiye'de yapılan lisansüstü tezlere tek merkezden erişim zorlu bir sürecin sonunda bugünkü hâlini almıştır. 2020 yılı itibari ile Yükseköğretim Kurulu (YÖK) bünyesinde bulunan Ulusal Tez Merkezi sayesinde yeni yayımlanan tüm tezlere elektronik ortamda erişim sağlanmaktadır. Süreç içerisinde Yükseköğretim Kurulu Başkanlığı farklı dönemlerde farklı sistemler kullanarak bir tez havuzu oluşturmaya çalışmış, bir miktar tezi havuza dâhil etmiş ancak bazı tezlere ulaşamamıştır (Yılmaz, 2002). İnternet teknolojisinin gelişimine paralel olarak elektronik ortamda tezlerin toplanması, araştırmacılar ve ilgililerin kullanımına açılması Ulusal Tez Merkezi sayesinde olmuştur. 1998 yılı öncesindeki lisansüstü tezler elektronik ortama tamamen aktarılmamıştır. Bu nedenle araştırmada, Türkiye'de 1998-2020 (Mart ayına kadar yayımlanan) yılları arasında yazılan ve gelişim alanlarından herhangi birini ya da birkaçını desteklediği belirtilen lisansüstü tezlerin amaç, yöntem ve sonuçları doğrultusunda incelenmesi amaçlanmış ve araştırma kapsamında eğitim amaçlı deneysel müdahalelerin okul öncesi dönem çocuklarının gelişim alanlarına etkisinin nasıl ve ne düzeyde olduğunun incelenmesi amaçlanmıştır.

Bu amaç kapsamında aşağıdaki soruların yanıtları aranmıştır:

1. Okul öncesi dönem çocuklarına uygulanan eğitim programları nelerdir?

2. Okul öncesi dönem çocuklarına uygulanan eğitim programlarının çocukların;

3. Gelişimleri üzerine etkisi nedir?

4. Gelişimlerine etki eden moderatör değişken var mıdır?

\section{Yöntem}

Araştırmada sistematik sentezleme yöntemlerinden biri olan meta analiz yöntemi kullanılmıştır. Meta analiz birbirinden bağımsız bireysel çalışmalardan elde edilen bulguların çeşitli istatistiksel teknikler kullanılarak sentezlenmesi ve yorumlanmasıdır. Meta analizin amacı gerçekleri ortaya çıkarabilmek için farklı zamanda, farklı yerlerde, aynı konuda yapılmış çalışmalardan elde edilen bulguları birleştirmek, örneklem büyüklügünü arttırmak yoluyla niceliksel olarak en doğruya ulaşabilmektir (Cumming, 2012).

\section{Çalışma Grubu}

Araştırmanın çalışma grubunu, Türkiye'de 1998 ile 2020 yılının Mart ayı (15/03/2020 tarihinde tarama sonlandırılmıştır) arasında yapılan, okul öncesi dönemdeki çocukların gelişim alanlarını 
desteklemeye yönelik 250 tez oluşturmaktadır. Deneysel desende tasarlanmış bu tezlerden, $154^{\prime}$ ü yüksek lisans, 96'sı ise doktora tezidir.

Araştırmaya dâhil edilen çalışmaların seçiminde kullanılan kriterler dört maddede aşağıda sunulmuştur.

1. Kriter 1: Meta analize dâhil edilen çalışmaların zaman aralığı: 1998-2020 (Mart ayına kadar yayınlananlar) yılları arasında yapılmış olmasıdır.

2. Kriter 2: Çalışma kaynakları: Türkiye'de normal gelişim gösteren okul öncesi dönem çocukları ile uygulanmış eğitimsel müdahale programlarını içeren yüksek lisans ve doktora tezleridir.

3. Kriter 3: Çalışmalardaki araştırma yönteminin uygun olması: Meta analiz çalışmalarında standartlaştırılmış etki büyüklügüne ulaşabilmek amacı ile dâhil edilen çalışmaların empirik (deneysel) çalışmalar olması öngörülmüştür.

4. Kriter 4: Yeterli sayısal veri içermesi: Meta analiz çalışması için gerekli olan etki büyüklüklerinin hesaplanabilmesi için, çalışmaya dâhil edilen araştırmaların betimleyici sayısal verilerine ihtiyaç duyulur. Bu nedenle örneklem büyüklüğü (n), aritmetik ortalama (ao) ve standart sapma (ss) değerlerini içeren çalışmalar araştırmaya dâhil edilmiştir.

Bir çalışmanın meta analize dâhil edilmemesi, çalışmanın araştırmanın sınırlamaları dışında kalması ya da meta analiz için gerekli istatistiksel verilere sahip olmamasından kaynaklanmaktadır (Card, 2012). Bu nedenle bu çalışmada kapsam dışında kalan çalışmaların özellikleri aşağıda sunulmuştur.

Meta analiz için çalışmaların nicel paradigmada tasarlanmış olması gerekmektedir. Bu nedenle bütün nitel çalışmalar araştırma dışında tutulmuştur. 1998-2020 (Mart ayına kadar yayımlanan) yılları dışında yayımlanmış tezler araştırmaya alınmamıştır. Okul öncesi dönem çocuklarının öğretmenleri, öğretmen adayları ve ebeveynlerine yönelik eğitimsel müdahale içeren çalışmalar kapsama dâhil edilmemiştir. Meta analizde çalışmaların birtakım istatistiki verilere sahip olması gerekmektedir. Bazı çalışmalardaki eksik verileri elde etmek için ulaşılması mümkün olan danışman ya da yazarlara e-posta ve telefon ile ulaşılmış ve eksik olan veriler elde edilmeye çalışılmıştır. Ancak bu girişimlere karşın istenilen kriterleri içermeyen çalışmalar araştırma dışında tutulmuştur. YÖK Ulusal Tez Merkezinde bazı çalışmalara erişim, yazar tarafından engellenmiştir. Bu çalışmalara ulaşmak amacı ile danışman ya da yazarlara e-posta ve telefon ile ulaşılmış ve veriler elde edilmeye çalışılmıştır. Bu yol ile de ulaşılamayan çalışmalar kapsam dışında bırakılmıştır.

Araştırmaya alınan tezlerin betimsel özelliklerine ilişkin frekans ve yüzdeler Tablo 1, 2, 3 ve 4'te sunulmuştur. 
Tablo 1. Meta Analize Dâhil Edilen Tezlerin Bazı Betimsel Özellikleri

\begin{tabular}{lll}
\hline Öğrenim Programı & $f$ & $\%$ \\
\hline Yüksek Lisans & 154 & 61,60 \\
Doktora & 96 & 38,40 \\
\hline Gelişim Alanı & & \\
\hline Bilişsel & 140 & 52,83 \\
Psikomotor & 28 & 10,57 \\
Sosyal Duygusal & 97 & 36,60 \\
\hline Okul Türü & & \\
\hline Kamu Bağımsız & 108 & 43,20 \\
Kamu İlköğretime Bağlı & 101 & 40,40 \\
Özel Bağımsız & 27 & 10,80 \\
Kamu Bağımsız/İlköğretim & 8 & 3,20 \\
Kamu/Özel Bağımsız & 5 & 2,00 \\
Okula Devam Etmeyen Çocuklar & 1 & 0,40 \\
\hline Yerleşim Yeri & & \\
\hline İl Merkezi/Merkez İlçe & 218 & 87,20 \\
İlçe Merkezi & 31 & 12,40 \\
Köy & 1 & 0,40 \\
\hline Toplam & 250 & 100,00 \\
\hline
\end{tabular}

Tablo 1 incelendiğinde tezlerin \%61,6'sının yüksek lisans, \%38,4'ünün doktora tezi olduğu, araştırmaya dâhil edilen tezlerin \%52,83'ünün bilişsel, \%10,57'sinin psikomotor, \%36,6'sının ise sosyal duygusal alana yönelik olduğu, tez kapsamındaki uygulamaların \%43,2'sinin kamu bağımsız anaokulunda, \%40,4'ünün kamu ilköğretime bağlı anaokulunda, \%10,8'inin özel bağımsız kurumlarda yapıldığ1 ve tezlerin çoğunluğunun $(\% 87,2)$ il merkezi/merkez ilçelerde, bir kısmının $(\% 12,4)$ ilçe merkezlerinde, sadece 1 adet tezin $(\% 0,4)$ köyde uygulamalarının gerçekleştirildiği görülmektedir.

Tablo 2. Meta Analize Dâhil Edilen Tezlerin Yazıldığı Üniversitelere Göre Dağılımı

\begin{tabular}{llc}
\hline Üniversite & $f$ & $\%$ \\
\hline Gazi & 53 & 21,20 \\
Selçuk & 29 & 11,60 \\
Marmara & 26 & 10,40 \\
Ankara & 23 & 9,20 \\
Hacettepe & 13 & 5,20 \\
Abant İzzet Baysal, Adnan Menderes & 10 & 4,00 \\
Çukurova & 6 & 2,40 \\
Kastamonu, Yıldız Teknik & 5 & 2,00 \\
Çanakkale Onsekiz Mart, Dokuz Eylül, Mersin & 4 & 1,60 \\
Akdeniz, Atatürk, İstanbul, İstanbul Okan, Muğla Sıtkı Koçman, & 3 & 1,20 \\
Pamukkale, Uludağ & & \\
Aksaray, Bahçeşehir, Dumlupınar, Ege, Firat, Gaziosmanpaşa, İnönü, & 2 & 0,80 \\
Karabük, Necmettin Erbakan, Ondokuz Mayıs, Orta Doğu Teknik, Recep & & \\
Tayyip Erdoğan, Trakya & & \\
Anadolu, Bartın, Erciyes, Gaziantep, Kırşehir Ahi Evran, Mustafa Kemal, & 1 & 0,40 \\
Sakarya, Trabzon, Üsküdar, Zonguldak Karaelmas, Polis Akademisi & & \\
Başkanlığı & & \\
\hline Toplam & 250 & 100,00 \\
\hline
\end{tabular}

Tablo 2 incelendiğinde, tezlerin, sırasıyla en çok Gazi Üniversitesi (53 adet), Selçuk Üniversitesi (29 adet), Marmara Üniversitesi (26 adet) ve Ankara Üniversitesi'nde (23 adet) yazılmış olduğu görülmektedir. 
Tablo 3. Meta Analize Dâhil Edilen Tezlerin Uygulandığı İllere Göre Dağılımı

\begin{tabular}{lcc}
\hline$\dot{I} l$ & $f$ & $\%$ \\
\hline Ankara & 50 & 20,00 \\
İstanbul & 38 & 15,20 \\
Konya & 19 & 7,60 \\
İzmir, Aydın, Adana & 9,60 \\
Bolu & 6 & 2,40 \\
Eskişehir, Kastamonu, Kayseri, Kocaeli & 5 & 2,00 \\
Antalya, Bursa, Düzce, Edirne, Karabük, Malatya, Samsun & 4,60 \\
Afyonkarahisar, Çanakkale, Mersin, Muğla, Tokat & 3,20 \\
Aksaray, Amasya, Bilecik, Burdur, Çankırı, Denizli, Elazı̆̆, Erzincan, Erzurum, & 2 & 0,80 \\
Kırıkkale, Kütahya, Nevşehir, Sivas, Tekirdağ, Uşak, Zonguldak & \\
Balıkesir, Batman, Bayburt, Gaziantep, Gümüşhane, Hatay, Kars, Kırşehir, Kilis, & 1 & 0,40 \\
Muş, Osmaniye, Rize, Sakarya, Sinop, Şanlıurfa & 250 \\
\hline Toplam & 100,00 \\
\hline
\end{tabular}

Tablo 3 incelendiğinde tezlerin en çok Ankara (50 adet), İstanbul (38 adet) ve Konya (19 adet) illerinde yapıldığı görülmektedir. İzmir, Aydın, Adana ve Bolu illerinde her birinde 9 adet, diğer illerde ise daha az sayıda tez çalışması yapıldığı görülmektedir.

Tablo 4. Meta Analize Dâhil Edilen Tezlerin Yazıldığğ Yıllara Göre Dağılımı

\begin{tabular}{lcc}
\hline Yll & $f$ & \% \\
\hline 1998 & - & - \\
1999 & 5 & 2,00 \\
2000 & 1 & 0,40 \\
2001 & - & - \\
2002 & 3 & 1,20 \\
2003 & 1 & 0,40 \\
2004 & 4 & 1,60 \\
2005 & 2 & 0,80 \\
2006 & 9 & 3,60 \\
2007 & 14 & 5,60 \\
2008 & 9 & 3,60 \\
2009 & 14 & 5,60 \\
2010 & 16 & 6,40 \\
2011 & 13 & 5,20 \\
2012 & 17 & 6,80 \\
2013 & 10 & 4,00 \\
2014 & 15 & 6,00 \\
2015 & 15 & 6,00 \\
2016 & 20 & 8,00 \\
2017 & 24 & 9,60 \\
2018 & 19 & 7,60 \\
2019 & 36 & 14,40 \\
2020 & 3 & 1,20 \\
\hline Toplam & 250 & 100,00 \\
\hline
\end{tabular}

Tablo 4 incelendiğinde yıllara göre araştırma kapsamında yazılan tezlerin sayısında genel olarak bir artış olduğu görülmektedir. Buna göre 2007 yılı öncesinde, yılda 10 adetten daha az tez yayımlanmışken sonraki yıllarda bu sayının arttı̆̆ gözlenmektedir. 1998 ve 2001 yıllarında ise araştırma kapsamına giren tezin bulunmadığı dikkat çekmektedir. 


\section{Veri Toplama Araçları}

Araştırma kapsamına alınan çalışmaların gruplanması ve daha sonraki aşamalarda istenilen verilere kolayca ulaşılabilmesi amacı ile araştırmacı tarafından "Kodlama Formu" oluşturulmuştur. Kodlama formu üç başlık altında hazırlanmıştır. Çalışma kimliği, çalışma içeriği, çalışma verileri belirlenen alt başlıklardandır. Çalışma kimliği kapsamında çalışmanın adı, numarası, yazarı, yılı, yapıldığı üniversite/enstitü ve türüne yer verilmiştir. Çalışma içeriği bölümü çalışmanın adı, uygulama süresi (hafta, gün, dakika), uygulama yapılan okul türü (kamu/özel, bağımsız/ilköğretime bağlı), uygulamanın yapıldığı şehir, uygulamanın yapıldığı yerleşim yeri (il merkezi/ilçe merkezi/köy), yaş grubu (ay cinsinden), veri toplama aracı, kullanılan analiz yöntemi ve müdahale sonunda katkı sağlanan gelişim alanına yer verilmiştir. Son olarak çalışma verileri bölümünde ise tezlerde belirtilen deney ve kontrol grubuna ait meta analiz çalışmasında istatistiksel işlemlerin yapılabilmesi için gerekli veriler (örneklem büyüklükleri, aritmetik ortalama, standart sapma vb.) bulunmaktadır. Kodlama formu okul öncesi eğitimi alanında beş, ölçme ve değerlendirme alanlarından iki akademisyenden görüş alındıktan sonra uygulamaya hazır hâle getirilmiştir.

\section{Verilerin Toplanması Süreci}

Araştırmaya yönelik ilk pilot tarama 2019 yılının Mart ayında 1998-2018 yıllarını kapsayacak şekilde yapılmıştır. Araştırmanın henüz planlama aşamasında yapılan bu tarama sonucunda veri doygunluğu tespit edilmiştir.

Araştırma kapsamında 20 Haziran 2019 ve 15 Mart 2020 tarihlerinde iki tarama yapılmıştır. Yapılan taramalarda aranacak alanların (yazar, danışman, konu, dizin, özet) tümü seçeneği kullanılarak ayrı ayrı "okul öncesi" ve "deney", "okulöncesi" ve "deney" "anasınıfı" ve "deney", "ana sınıfı" ve "deney", "erken çocukluk" ve "deney" ve "erken çocukluk eğitimi" ve "deney" anahtar kelimeleri ile taramalar yapılmıştır. Anahtar kelimelerden ilki "yazıldığı gibi", ikincisi ise "içinde geçsin" seçeneği seçilerek taramalar yapılmıştır.

Meta analiz çalışmalarında kodlama güvenirliğinin sağlanması önerilmektedir (Card, 2012). Kodlama güvenirliğinin analizi için toplamda elde edilen 366 tezden çalışmanın dâhil edilme kriterlerine uygun olan ve rastgele seçilen 10 tez okul öncesi eğitimi alanında çalışan iki akademisyene kodlama formu ile birlikte mail ortamında gönderilmiştir. Belirlenen 10 tez bir hafta süre zarfında iki uzman ve araştırmacı tarafından ayrı ayrı kodlama tablosuna girilmiştir. Sonrasında kodlayıcılar arasındaki güvenirliği belirlemek için "uzlaşma sayısı/uzlaşma+uzlaşmama sayısı" formülünden yararlanılmıştır. Kodlayıcılar arasındaki uygunluğun \%70'in üzerinde olması güvenirliğin yeterli olduğunu göstermektedir (Tavşancıl ve Aslan, 2001). Yapılan hesaplama sonucunda araştırmacı ile birinci uzman arasında \%99, ikinci uzman arasında \%98 uygunluk tespit edilmiştir. 
Kodlayıcı güvenirliğinin makul olduğunun anlaşılmasının ardından kodlama tablosuna veri girişi yapılmaya başlanmıştır. 1998-2019 yıllarına ait 363, 2019-2020 yıllarına ait 74 olmak üzere toplamda 437 tezin verileri detaylı bir şekilde incelenmiştir. Yapılan incelemeler sonucunda özel gereksinimli, üstün yetenekli çocuklar ile çalışılmış ya da kaynaştırma sınıflarında uygulanmış 8; okul müdürü, öğretmen, öğretmen adayı ve ebeveynler ile uygulanmış ya da farklı araştırma deseninde (nitel, tek gruplu deneysel desen vb.) olan 43 ve yazarlar tarafından erişimi kısıtlı 37, eksik/tutarsız veri bulunan 99 tez çalışma dışında tutulmuştur. Veri eksikliği ve erişim engeli bulunan tezlerden danışmanlarına ya da yazarlarına ulaşılması mümkün olanlar veri girişi sürecinde telefon veya eposta ile iletişim kurulmuş geri dönüş gerçekleştirilen çalışmaların verileri alınmıştır. Nihayetinde 15 Nisan 2020 tarihinde veri girişi sonlandırılmış ve 154'ü yüksek lisans, 96'sı doktora tezi olmak üzere toplam 250 lisansüstü tez meta analize dâhil edilmiştir. 1998-2019 yılları arasında ulaşılan 980 ve 20192020 yılları arasında ulaşılan 200 tezden meta analize dâhil edilen 250 tezin nasıl indirildiğini gösteren akış diyagramı Şekil 1'de verilmiştir.

\section{Verilerin Analizi}

Araştırmada ortalama etkinin belirlenmesi için sabit etkiler ve rastgele etkiler modeline göre birleştirmeler yapılmış, hangi sonucun kullanılabileceğinin belirlenmesi için homojenlik testi, huni saçılım grafiği ve Duval ve Tweedie'nin (2000) Trim and Fill testleri yapılmıştır. Ayrıca moderatör olabileceği düşünülen altı değişken için meta regresyon analizi yapılmıştır. Bununla birlikte cinsiyet değişkenine ilişkin sabit etkiler ve rastgele etkiler modeline birleştirmeler yapılmıştır. Araştırmada meta analizde, değerlendirilmek üzere “Cohen's d" etki büyüklüğü istatistiği kullanılmıştır. Cohen's d istatistiği, iki grubun aritmetik ortalamalar farkının ortak standart sapmaya bölünmesi ile gruplar arası farklılı̆̆ın standardize edilmesine dayanmaktadır. Yapılan standardizasyon işlemi, farklı ölçeklerin kullanıldığı çalışmaların meta analizde birlikte değerlendirilebilmesi imkânını sunmaktadır ve iki grup ortalamasının birbirinden kaç standart sapma farklılık gösterdiğini ifade etmektedir.

Meta analiz ile ortak etki büyüklüğü kestirimi hem sabit etkiler hem de rastgele etkiler modellerine göre yapılmıştır. Analize dâhil edilen tezlerin etki büyüklükleri dağılımının heterojenlik yapısı, $Q$ testine ve aynı zamanda $I^{2}$ istatistiğine göre belirlenmiştir. $Q$ istatistiğinin bir tamamlayıcısı olarak geliştirilen $\mathrm{I}^{2}$ istatistiği, heterojenliğe ilişkin daha net bir sonuç ortaya koymaktadır (Petticrew ve Roberts, 2006). I'nin yorumlanmasında, \%25 düşük düzeyde heterojenliği, \%50 orta düzeyde heterojenliği ve \%75 yüksek düzeyde heterojenliği göstermektedir (Cooper, Hedges ve Valentine, 2019). 


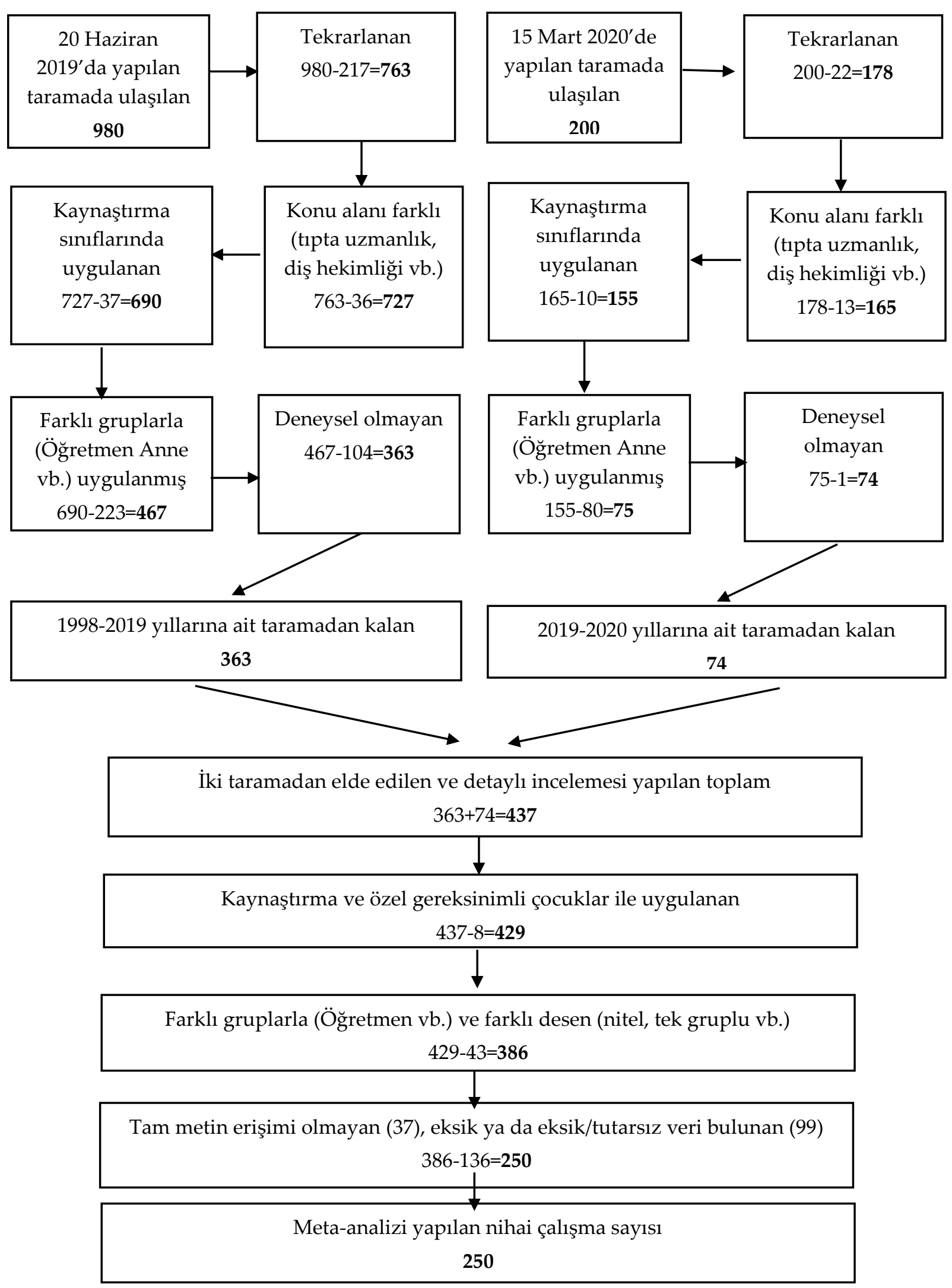

Şekil 1. Araştırmaya Alınan Tezlere Ulaşılmasına İlişkin Akış Diyagramı 
Etki büyüklüğü dağllımının $Q$ testi ve $\mathrm{I}^{2}$ istatistiğine göre, heterojen olduğunun belirlenmesi durumunda rastgele etkiler modeline göre yapılan kestirimler göz önünde bulundurulmuştur.

Etki büyüklüklerinin dağılımındaki heterojenliğe neden olan faktörlerin araştırılmasında, meta-regresyon analizi ve alt-grup analizlerinden yararlanılmıştır. Meta-regresyon analizinde etki büyüklüğü bağımlı değişken ve heterojenliğe neden olabileceği öngörülen faktörler, bağımsız değişken olmak üzere bağımsız değişkenlerin etki büyüklüğü üzerine etkisi olup olmadığı incelenmiş, modelin istatistiksel anlamlılığı Cochran $Q$ testi ile değerlendirilmiştir. Alt-grup analizinde ise bağımsız değişken olarak değerlendirilen faktörlerin her bir alt kategorisine ait etki büyüklüğü kestirimleri yapılmış ve bu kestirimler arasındaki farklılıklar gözlenmiştir.

Araştırmaya dâhil edilen çalışmalardan elde edilen verilerin analizinde Comprehensive MetaAnalysis V3.0 (CMA) yazılımı deneme sürümünden faydalanılmıştır.

\section{Bulgular}

Analizler sonucunda ortaya çıkan sabit ve rastgele etkiler modeli birleştirmeleri, homojenlik testi, yayın yanlılığı bulguları aşağıda sunulmuştur. Meta analize dâhil edilen toplam 246 çalışmaya ait orman grafiklerine ilişkin bilgi makalenin sonunda araştırmacının notu kısmında verilmiştir.

Tablo 5. Gelişim Puanlarına İlişkin Meta Analizinin Sabit-Rastgele Etkiler Modeline Göre Birleştirilmiş Sonuçları

\begin{tabular}{lccccccc}
\hline Model & $\begin{array}{c}\text { Etki } \\
\text { Büyüklü̆̈̈̈ } \\
(\boldsymbol{d})\end{array}$ & $\begin{array}{c}\text { Standart } \\
\text { Hata }\end{array}$ & Varyans & $\begin{array}{c}\text { Alt } \\
\text { Sinır }\end{array}$ & $\begin{array}{c}\text { Üst } \\
\text { Sinır }\end{array}$ & Z Değeri & $p$ \\
\hline Sabit Etkiler Modeli & 0,750 & 0,020 & 0,000 & 0,711 & 0,788 & 37,926 & $<0,001$ \\
Rastgele Etkiler Modeli & 1,102 & 0,070 & 0,005 & 0,965 & 1,238 & 15,816 & $<0,001$ \\
\hline
\end{tabular}

Meta analize dâhil edilen tezlerin gelişim puanı sonuçları sabit etkiler modeline göre, birleştirilen ortalama etki büyüklüğü değeri $\mathrm{ES}=0,750$, ortalama etki büyüklüğünün standart hatası $\mathrm{SE}=0,020$, ortalama etki büyüklügünün güven aralığı alt sınırı 0,711 ve üst sinırı 0,788 olarak hesaplanmıştır. Rastgele etkiler modeline göre, meta analize dâhil edilen tezlerin, standart hatası ise $\mathrm{SE}=0,070, \% 95$ güven aralığının alt sınırı 0,965 ve üst sınırı 1,238 ile tezlerin ortak etki büyüklüğü $\mathrm{ES}=1,102$ olarak hesaplanmıştır.

Tablo 6. Gelişim Puanlarına İlişkin Etki Büyüklüğü Dağılımının Homojenlik Testi Sonuçları

\begin{tabular}{|c|c|c|c|}
\hline$Q$ değeri & $d f(Q)$ & $p$ & $I^{2}$ değeri \\
\hline 2907,206 & 245,000 & $<0,001$ & 91,573 \\
\hline
\end{tabular}

Homojenlik testine (Q testi) göre, $Q=2907,206$ olarak hesaplanmıştır. $\chi 2$ tablosundan \%95 anlamlılık düzeyinde 245 serbestlik derecesi değeri 282,511 olarak bulunmuştur. Q-istatistik değeri $(\mathrm{Q}=2907,206) 245$ serbestlik derecesi ile Ki-kare dağılımının kritik değerini $(\chi 20,95=282,511)$ aştığı için etki büyüklüklerinin dağılımına ait homojenliğin yokluk hipotezi sabit etkiler modeline göre reddedilmiştir $(\mathrm{p}<0,001)$. Bir başka ifade ile etki büyüklükleri dağılımının sabit etkiler modeline göre 
heterojen bir özelliğe sahip olduğu belirlenmiştir. $I^{2}$ değerinin $\% 75$ düzeyinin oldukça üzerinde (I2=91,573) olması, sabit etkiler modeline göre hesaplanan etki büyüklüklerinin dağılımının heterojen bir özelliğe sahip olduğunu göstermektedir. Buna göre rastgele etkiler modelinin kullanımı uygundur.

Rastgele etkiler modeline göre yapılan birleştirmelerde istatistiksel anlamlılık Z testine göre hesaplandığında $Z=15,816$ olarak bulunmuştur. Buna göre gelişime ait puanların değerlendirmesinde deney grubu ile kontrol grubu arasında istatistiksel olarak fark olması $(\mathrm{p}<0,001)$ ve ortak etki büyüklüğünün pozitif olması (ES=1,102) nedeniyle sonuçların deney grubu lehine olduğu belirlenmiştir. Rastgele etkiler modeline göre yapılan analiz sonucunda elde edilen 1,102 değeri Cohen'in (1988) sınıflandırmasına göre büyük etki büyüklügü, Thalheimer ve Cook'un (2002) sınıflamasına göre ise çok büyük etki büyüklügü olarak kabul edilmektedir.

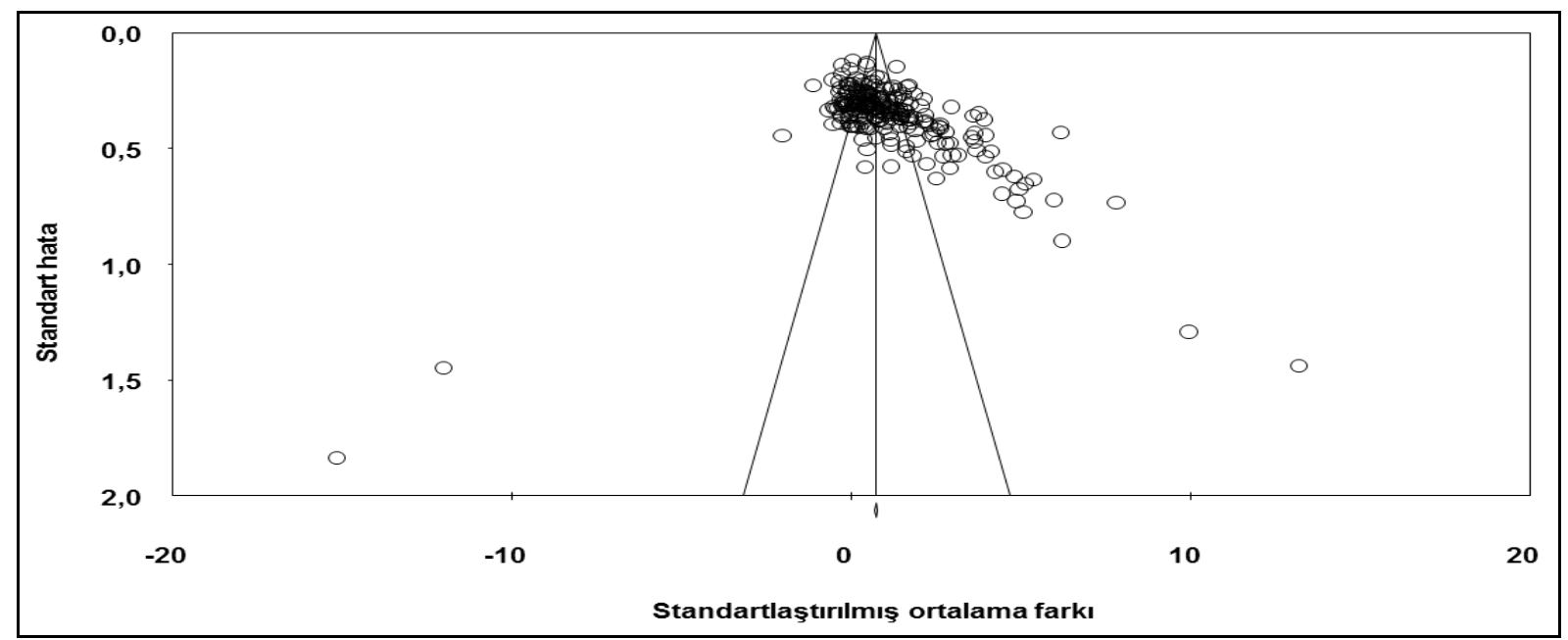

Şekil 2. Gelişim Puanlarına İlişkin Etki Büyüklükleri Huni Saçılım Grafiği

Huni grafiğine göre etki büyüklükleri ile standart hatalarının dağılımının simetrik olmadığı, bu durumun yayın yanlılığı göstergesi olabileceği düşünülmüştür. Huni grafiğinin saçılımı, büyük etki büyüklüğüne ve küçük standart hataya (dolayısıyla geniş örneklem büyüklüguüne) sahip çalışmaların yayımlanma eğiliminde olduğuna işaret etmektedir.

Tablo 7. Gelişim Puanları Yayın Yanlılığı İçin Duval ve Tweede's Trim and Fill Testi Sonuçları

\begin{tabular}{|c|c|c|c|c|c|c|c|c|}
\hline & & \multicolumn{3}{|c|}{ Sabit Etkiler Modeli } & \multicolumn{3}{|c|}{ Rastgele Etkiler Modeli } & \multirow[b]{2}{*}{$Q$ değeri } \\
\hline & $\begin{array}{c}\text { Eklenen } \\
\text { çalışma } \\
\text { sayısı }\end{array}$ & $\begin{array}{c}\text { Etki } \\
\text { Büyüklü̈̆̈̈u } \\
\text { (d) }\end{array}$ & $\begin{array}{c}\text { Alt } \\
\text { Sintr }\end{array}$ & $\begin{array}{c}\text { Üst } \\
\text { Stnır }\end{array}$ & $\begin{array}{c}\text { Etki } \\
\text { Büyüklüŭg̈ü } \\
\text { (d) }\end{array}$ & $\begin{array}{c}\text { Alt } \\
\text { Sinir }\end{array}$ & $\begin{array}{c}\text { Üst } \\
\text { Sinır }\end{array}$ & \\
\hline $\begin{array}{l}\text { Gözlenen } \\
\text { değerler }\end{array}$ & & 0,750 & 0,711 & 0,788 & 1,102 & 0,965 & 1,238 & 2907,206 \\
\hline $\begin{array}{l}\text { Düzeltilen } \\
\text { değerler }\end{array}$ & 55 & 0,489 & 0,452 & 0,530 & 0,494 & 0,338 & 0,651 & 5194,455 \\
\hline
\end{tabular}

Duval ve Tweedie (2000) Trim and Fill testine göre, huni grafiğindeki asimetriyi gidermeye yönelik 55 tez eklenmesi gerektiği belirlenmiştir. 


\section{Moderatör Analizi}

Gelişime ait birleştirilmiş ortalama etki büyüklüğünün hetorojenliğinin açıklanabilmesi için altı adet moderatör analizi yapılmıştır. Bu değişkenler uygulamanın yapıldığı toplam hafta, bir haftadaki oturum sayısı, uygulamanın yapıldığı gruptaki çocuk sayısı, uygulamanın yapıldığı toplam dakika, her bir oturumun uygulama süresi ve uygulamanın yapıldığı yaş grubu olarak belirlenmiştir. Her bir moderatör değişken için farklı kombinasyonlarda analizler yapılmıştır. Örneğin bir haftadaki oturum sayısı iki gün ve altı, iki gün üzeri; üç gün ve altı, üç gün üzeri; dört gün ve altı, dört gün üzeri gibi farklı analizler yapılarak moderatör tespit edilmeye çalışılmıştır. Analizler sonucunda toplam dakika, her bir oturumun uygulama süresi ve uygulamanın yapıldı̆̆ı yaş grubu değişkenlerinde ortalama etki büyüklüğündeki hetorojenliği açıklayabilecek bir moderatör etkisi bulunmamıştır.

Tablo 8. Moderatör Analizi Sonuçları

\begin{tabular}{|c|c|c|c|c|c|c|c|c|c|c|c|}
\hline \multirow[b]{2}{*}{ Toplam Hafta } & \multirow[b]{2}{*}{$n$} & \multirow[b]{2}{*}{$E S$} & \multirow[b]{2}{*}{$S E$} & \multicolumn{2}{|c|}{$\% 95 C I$} & \multirow[b]{2}{*}{$Z$} & \multirow[b]{2}{*}{$p$} & \multirow[b]{2}{*}{$Q$} & \multicolumn{3}{|c|}{ Homojenlik } \\
\hline & & & & $\begin{array}{c}\text { Alt } \\
\text { limit }\end{array}$ & $\begin{array}{c}\text { Üst }_{\text {limit }} \\
\text { limis }\end{array}$ & & & & $s d$ & $p$ & $I^{2}$ \\
\hline 10 hafta altı & 113 & 0,715 & 0,029 & 0,658 & 0,772 & 24,556 & $<0,001$ & 929,059 & 112 & $<0,001$ & 87,945 \\
\hline 10 hafta ve üzeri & 130 & 0,765 & 0,027 & 0,712 & 0,818 & 28,194 & $<0,001$ & 1948,222 & 129 & $<0,001$ & 93,379 \\
\hline \multicolumn{12}{|c|}{ Haftalık Oturum Sayısı } \\
\hline 3 gün ve altı & 36 & 0,733 & 0,046 & 0,642 & 0,824 & 15,812 & $<0,001$ & 655,293 & 35 & $<0,001$ & 94,659 \\
\hline 3 gün üzeri & 206 & 0,740 & 0,022 & 0,697 & 0,783 & 33,640 & $<0,001$ & 2211,110 & 205 & $<0,001$ & 90,729 \\
\hline \multicolumn{12}{|c|}{ Gruptaki Çocuk Sayısı } \\
\hline 20 alt1 & 89 & 0,877 & 0,044 & 0,790 & 0,963 & 19,918 & $<0,001$ & 842,998 & 88,000 & $<0,001$ & 89,561 \\
\hline 20 ve üzeri & 157 & 0,718 & 0,022 & 0,674 & 0,761 & 32,436 & $<0,001$ & 2053,781 & 156,000 & $<0,001$ & 92,404 \\
\hline
\end{tabular}

Meta analizde elde edilen ortak etki büyüklügüüne eğitimsel uygulamanın toplam haftasının etkisi ile ilgili meta regresyon modelinin istatistiksel önem kontrolü Cochrane $Q$ Testi ile yapılmış ve modelin istatistiksel olarak anlamlı olduğu sonucu elde edilmiştir $(\mathrm{Q}=5,09, \mathrm{df}=1, \mathrm{p}=0,024)$. Buna göre, eğitim uygulanan sürenin 10 haftadan daha az olduğu tezlerin ortak etki büyüklükleri ile 10 hafta ve üzerinde olan tezlerin ortak etki büyüklükleri arasında istatistiksel olarak anlamlı fark bulunmuştur ( $\mathrm{p}=0,024) .10$ haftadan daha az süre eğitim uygulanan tezlerdeki etki büyüklükleri ortalaması ES=0,715 iken; 10 hafta ve daha fazla süre eğitim uygulanan tezlerin ortak etki büyüklüğü ortalaması ES=0,765 olarak gözlenmiştir.

Meta analizde elde edilen ortak etki büyüklügüne haftalık oturum sayısının etkisi ile ilgili meta regresyon modelinin istatistiksel önem kontrolü Cochrane $Q$ Testi ile yapılmış ve modelin istatistiksel olarak anlamlı olduğu sonucu elde edilmiştir $(\mathrm{Q}=4,81, \mathrm{df}=1, \mathrm{p}=0,028)$. Buna göre, eğitim uygulanan sürenin haftada 3 gün ve daha az olduğu tezlerin ortak etki büyüklükleri ile 3 günün üzerinde olan tezlerin ortak etki büyüklükleri arasında istatistiksel olarak anlamlı fark bulunmuştur $(p=0,028)$. Üç gün ve daha az süre eğitim uygulanan tezlerdeki etki büyüklükleri orta büyüklükte iken (ES=0,733); üç günden daha fazla süre eğitim uygulanan tezlerin ortak etki büyüklüğü yine orta büyüklükte ancak daha yüksek ( $E S=0,740)$ olarak gözlenmiştir. 
Meta analizde elde edilen ortak etki büyüklüğüne deney grubundaki çocuk sayısının etkisi ile ilgili meta regresyon modelinin istatistiksel önem kontrolü Cochrane Q Testi ile yapılmış ve modelin istatistiksel olarak anlamlı olduğu sonucu elde edilmiştir $(Q=0,67, d f=1, p=0,413)$. Buna göre, deney grubundaki çocuk sayısı 20'nin altında olduğu tezlerin ortak etki büyüklükleri ile 20 ve üzerinde olduğu tezlerin ortak etki büyüklükleri arasında istatistiksel olarak anlamlı fark bulunmuştur $(p=0,413)$. Deney grubundaki çocuk sayısı 20'nin altında olduğu tezlerdeki ortak etki büyüklüğü büyük etki büyüklüğü iken ( $\mathrm{ES}=0,877) ; 20$ ve üzerinde olduğu tezlerin ortak etki büyüklükleri orta büyüklükte $(\mathrm{ES}=0,718)$ olarak gözlenmiştir.

\section{Cinsiyet Değişkeni ile İlgili Bulgular}

Meta analiz kapsamında veri toplama sürecinde lisansüstü tezlerde deney grubundaki çocukların cinsiyet, kardeş varlığı, doğum sırası, daha önceki yıllarda okul öncesi eğitim alıp almama durumu, anne yaşı, anne öğrenim düzeyi, anne çalışma durumu, baba yaşı, baba öğrenim düzeyi gibi demografik durumlarıyla ilgili herhangi bir veri olup olmadığına bakılmıştır. Bu değişkenlerden cinsiyet değişkeni dışındaki değişkenlerin meta analiz yapılabilecek sayıda olmamasından kaynaklı olarak sadece cinsiyet değişkeninin verileri analiz edilmiştir. Cinsiyet değişkeni ile ilgili sabit etkiler modeli ve rastgele etkiler modeli, homojenlik testi ve yayın yanlılığı bulguları aşağıda sunulmuştur.

Tablo 9. Deney Grubundaki Çocukların Cinsiyetlerine İlişkin Meta Analizinin Sabit-Rastgele Etkiler Modeline Göre Birleştirilmiş Sonuçları

\begin{tabular}{lccccccc}
\hline Model & $\begin{array}{c}\text { Etki } \\
\text { Büyüklüğ̈̈ } \\
(\boldsymbol{d})\end{array}$ & $\begin{array}{c}\text { Standart } \\
\text { Hata }\end{array}$ & Varyans & $\begin{array}{c}\text { Alt } \\
\text { Sinır }\end{array}$ & $\begin{array}{c}\text { Üst } \\
\text { Sinır }\end{array}$ & $\begin{array}{c}Z \\
\text { Değeri }\end{array}$ & $p$ \\
\hline Sabit Etkiler Modeli & 0,040 & 0,057 & 0,003 & $-0,072$ & 0,151 & 0,696 & 0,486 \\
Rastgele Etkiler Modeli & 0,027 & 0,064 & 0,004 & $-0,099$ & 0,152 & 0,415 & 0,678 \\
\hline
\end{tabular}

Cinsiyet değişkeni ile ilgili yapılan meta analize dâhil edilen tezlerin sabit etkiler modeline göre birleştirilen ortalama etki büyüklüğü $E S=0,040$, ortalama etki büyüklüğünün standart hatası $\mathrm{SE}=0,057$, ortalama etki büyüklüğünün güven aralığı alt sınırı -0,072 ve üst sınırı 0,151 olarak hesaplanmıştır. Cinsiyet değişkeni ile ilgili yapılan meta analize dâhil edilen tezlerin rastgele etkiler modeline göre birleştirilen ortalama etki büyüklüğü $\mathrm{ES}=0,027$, ortalama etki büyüklüğünün standart hatası SE=0,064, ortalama etki büyüklüğünün güven aralığı alt sınırı -0,099 ve üst sinırı 0,152 olarak hesaplanmıştır.

Tablo 10. Deney Grubundaki Çocukların Cinsiyetlerine İlişkin Puanların Etki Büyüklüğü Dağılımının Homojenlik Testi Sonuçları

\begin{tabular}{cccc}
\hline$Q$ değ eri & $d f(Q)$ & $p$ & $I^{2}$ dĕ̆eri \\
\hline 42,279 & 36,000 & 0,218 & 14,851 \\
\hline
\end{tabular}

Homojenlik testine ( $Q$ testi) göre, $Q=42,279$ olarak hesaplanmıştır. $\chi 2$ tablosundan \%95 anlamlılık düzeyinde 36 serbestlik derecesi değeri 50,998 olarak bulunmuştur. Q-istatistik değeri $(Q=42,279) 36$ serbestlik derecesi ile Ki-kare dağılımının kritik değerinden $(\chi 20,95=50,998)$ küçük bir 
değer olduğu için etki büyüklüklerinin dağılımına ait homojenliğin yokluk hipotezi sabit etkiler modeline kabul edilmiştir ( $\mathrm{p}<0,001)$. Bir başka ifade ile etki büyüklükleri dağılımının sabit etkiler modeline göre, homojen bir özelliğe sahip olduğu belirlenmiştir. Homojenlik testi sonuçlarına göre, sabit etkiler modelinin kullanılması uygundur. Heterojenlik indeksi $I^{2}$ değeri $(I 2=14,851)$ düşük düzeyin (\%25) altında olduğundan sabit etkiler modelinin kullanımının uygun olduğu belirlenmiştir. Sabit etkiler modeline göre, cinsiyet değişkenine ait son test değerlendirmesinde kız çocukları ile erkek çocukları arasında istatistiksel olarak anlamlı fark bulunmadığı belirlenmiştir $(p=0,486)$.

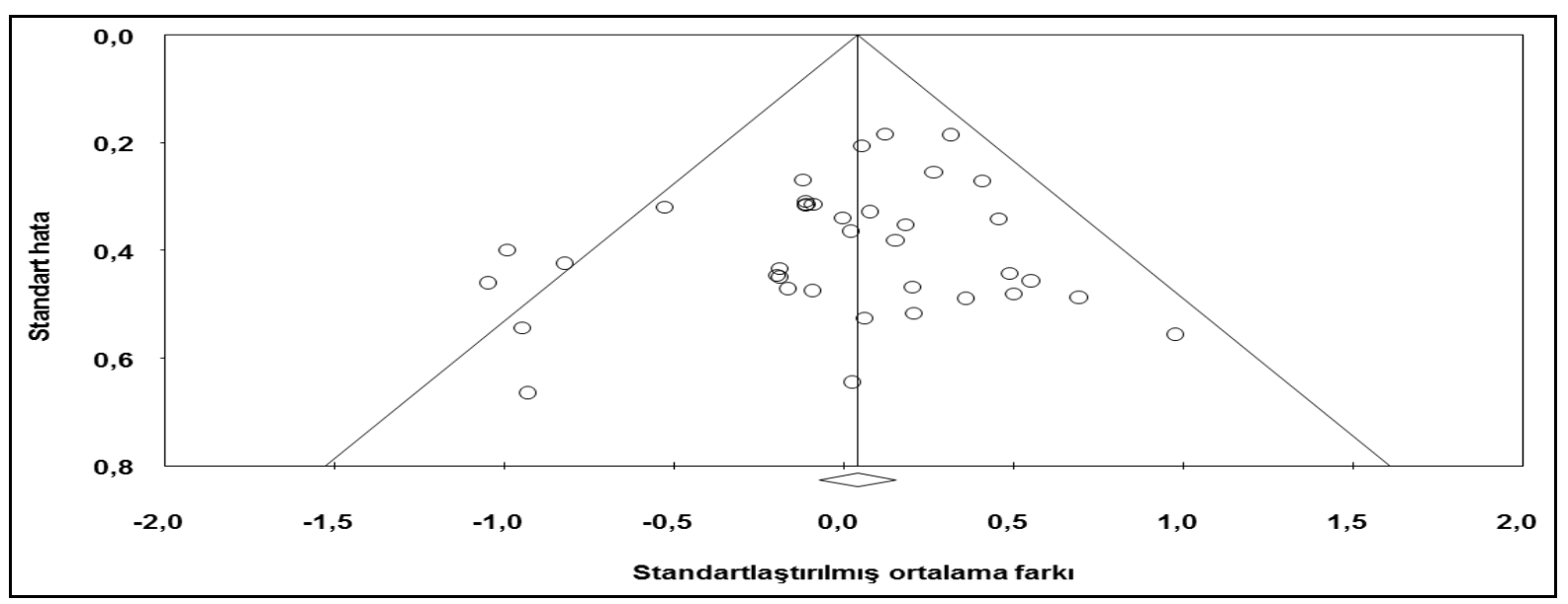

Şekil 3. Deney Grubundaki Çocukların Cinsiyetlerine İlişkin Puanların Etki Büyüklükleri Huni Saçılım Grafiği

Huni saçılım grafiğine göre etki büyüklükleri ile standart hatalarının saçılımı homojen olduğundan yayın yanlılığı bulunmadığı belirlenmiştir. Duval ve Tweedie's (2000) Trim and Fill testi sonucunda, yayın yanlılığının giderilmesi için eklenmesi gereken herhangi bir tez olmadığı belirlenmiş, huni grafiğinin sonuçları desteklenmiştir.

Tablo 11. Deney Grubundaki Çocukların Cinsiyetlerine İlişkin Puanların Yayın Yanlılığı İçin Duval ve Tweede's Trim and Fill Testi Sonuçları

\begin{tabular}{|c|c|c|c|c|c|c|c|c|}
\hline & \multicolumn{4}{|c|}{ Sabit Etkiler Modeli } & \multicolumn{3}{|c|}{ Rastgele Etkiler Modeli } & \multirow[b]{2}{*}{$Q$ değeri } \\
\hline & $\begin{array}{c}\text { Eklenen } \\
\text { çalışma } \\
\text { sayısı }\end{array}$ & $\begin{array}{c}\text { Etki } \\
\text { Büyükliü̆̈̈̈ } \\
(d)\end{array}$ & Alt Sinır & $\begin{array}{l}\text { Üst } \\
\text { Stner }\end{array}$ & $\begin{array}{c}\text { Etki } \\
\text { Büyükliü̆̈̈̈ } \\
(d)\end{array}$ & Alt Sinır & $\begin{array}{c}\text { Üst } \\
\text { Sinir }\end{array}$ & \\
\hline $\begin{array}{l}\text { Gözlenen } \\
\text { değerler }\end{array}$ & & 0,040 & $-0,072$ & 0,151 & 0,027 & $-0,099$ & 0,152 & 42,279 \\
\hline $\begin{array}{l}\text { Düzeltilen } \\
\text { değerler }\end{array}$ & 0 & 0,040 & $-0,072$ & 0,151 & 0,027 & $-0,099$ & 0,152 & 42,279 \\
\hline
\end{tabular}

\section{Tartışma}

Okul öncesi dönem çocuklarının gelişimlerini destekleyen 246 lisansüstü tezin meta analizi sonucunda tezlerde uygulanan eğitimsel müdahalelerin çocukların gelişimlerine önemli katkıları olduğu sonucuna ulaşılmıştır (ES=1,102). Sistematik sentezleme türlerinden olan oy sayma yöntemi ile 
değerlendirildiğinde eğitimsel müdahale sonrasında uygulanan son testlerde 246 tezin 205'inde istatistiksel olarak anlamlı farklılık tespit edilmiştir.

Alvarez-Bueno vd.'nin (2017) fiziksel aktivite müdahalelerinin çocuklukta akademik başarı ve sınıf içi davranışlar üzerindeki etkisini inceledikleri çalışmada, fiziksel aktiviteyi destekleyici müdahalelerin dil gelişimine (0.16), matematikle ilişkili becerilere (0.21), okuma yazma becerilerine (0.13) ve genel becerilere (0.26) hafif düzeyde bir etkisi olduğu bulunmuştur. Fukking vd.'nin (2017) erken çocukluk müdahalelerinin çocukların gelişimi üzerindeki etkisini inceledikleri çalışmada, bu çalışmadan farklı olarak uygulanan erken çocukluk müdahalelerinin çocukların bilişsel ve sosyal duygusal gelişimine etkisinin olmadığı saptanmıştır. Schimmel'in (2018) okul öncesi eğitime katılım ile akademik başarı ve sosyal duygusal alan arasındaki ilişkiyi incelediği çalışmada ise okul öncesi eğitim alan çocuklar ile almayan çocuklar arasında akademik başarı ve sosyal duygusal yönden bir fark olmadığı saptanmıştır.

Gelişim ile ilgili eğitimsel müdahalelerin toplam haftası, haftalık oturum sayısı ve uygulama yapılan gruptaki çocuk sayısı ile ilgili yapılan moderatör analizlerinde ise anlamlı farklılık tespit edilmiştir. Eğitim süresi 10 hafta ve üzerinde olan, haftada üç gün üzerinde eğitim uygulanan ve uygulama yapılan gruptaki çocuk sayısı 20'nin altında olan tezlerin etki büyüklüklerinin daha yüksek olduğu belirlenmiştir.

Uygulama yapılan gruptaki çocuk sayısının 20'nin altında olmasının eğitimsel müdahalenin etkisini arttırdığı sonucuna paralel olarak Bowne, Magnuson, Schindler, Duncan ve Yoshikawa (2017) okul öncesi eğitim programlarında sınıf büyüklükleri ve oranlarının bilişsel, akademik başarı ve sosyal duygusal sonuçlar üzerindeki etkisini inceledikleri çalışmada, fiziksel alanın küçük olmasının ve çocuk öğretmen oranının yüksekliğinin bilişsel gelişimi ve akademik başarıyı olumsuz yönde etkilediği saptanmıştır.

Wick vd.'nin (2017) anaokulunda temel hareket becerilerini geliştirmeye yönelik müdahaleleri inceledikleri çalışmada, temel motor beceriler açısından dört veya beş hafta süre ile uygulanan müdahalelerin altı hafta ve daha uzun süre uygulanan müdahalelere göre daha yüksek etki büyüklügüune sahip olduğu saptanmıştır. Bu araştırmada ise 10 hafta ve üzerinde uygulanan eğitimin 10 hafta altında uygulanan eğitime göre daha yüksek etki büyüklüğüne sahip olduğu belirlenmiştir.

Meta analize dâhil edilen 37 tezde eğitimsel müdahalelerin cinsiyet değişkeni üzerinde etkisi olmadığı sonucuna ulaşılmıştır. Başka bir ifadeyle uygulanan eğitimsel müdahaleler kız çocukları ile erkek çocukları benzer şekilde etkilemektedir. Alan yazında benzer sonuçları ortaya koyan meta analiz araştırmaları mevcuttur. Bu sonuca benzer olarak Cho (2004) özel gereksinimi olan çocuklar ile akranları arasındaki sosyal etkileşimlerini incelediği meta analiz çalışmasında cinsiyetler arasında farkın olmadığını tespit etmiştir. 


\section{Sonuç}

Türkiye'de 1998 yılından 2020 yılının ilk üç ayını içine alan süreçte her yıl giderek artan sayıda okul öncesi dönem çocuklarının gelişimlerini destekleyici lisansüstü tez çalışması yapılmıştır. Bu lisansüstü tez çalışmaları sonucunda istatistiksel olarak hem anlamlı hem de anlamlı olmayan sonuçlara ulaşılmıştır. Okul öncesi dönem yaş grubundaki çocukların gelişimlerini destekleyici bu çalışmaların sonuçlarını bir araya getirip sentezleyebilmek ve bu konuda yeni yapılacak olan araştırmalara yön verebilmek için bir meta analiz çalışmasına ihtiyaç duyulmuştur. Ayrıca meta analiz sayesinde bireysel çalışmalarda ele alınması mümkün olmayan moderatör değişkenler aracılığıyla araştırma sonuçlarının farklılığının açıklanması amaçlanmıştır.

Okul öncesi dönem çocuklarına yönelik eğitimsel müdahalelerin meta analiz yöntemiyle değerlendirilmesi amaçlanan bu çalışmada 1998-2020 (Mart ayına kadar yayımlanan) yılları arasında araştırma kapsamına 154'ü yüksek lisans, 96'sı doktora olmak üzere toplam 250 tez dâhil edilmiştir. Bu 250 tezin 140'ının bilişsel gelişim, 28'inin psikomotor gelişim ve 97'sinin sosyal duygusal gelişim alanına katkı sağladığı görülmüştür. Lisansüstü tezlerdeki eğitimsel müdahaleler daha çok kamuya ait olan bağımsız anaokullarında uygulanmıştır. Eğitimsel müdahale programlarının, Türkiye genelinde 54 farklı şehirde, çoğunlukla il merkezi ya da merkez ilçede uygulandığı belirlenmiştir. Tezlerin yayımlandığı üniversite olarak en fazla Gazi Üniversitesi'nin, enstitü türü olarak ise eğitim bilimleri enstitüsünün olduğu saptanmıştır. Yıllara göre, her yıl giderek artan sayıda tezin tamamlanmakta olduğu tespit edilmiştir.

YÖK Ulusal Tez Merkezi üzerinden yapılan taramalarda bazı tezlere erişimin sınırlandırıldığı görülmüştür. Bu durum birincil çalışmalara ulaşımı engellediğinden meta analiz çalışmalarının yapılmasını zorlaştırmaktadır. YÖK Ulusal Tez Merkezi tarama sayfasında tez ve yazara ait bazı bilgiler bulunmaktadır. Ancak yazara ait elektronik posta adresi bulunmadığından erişim engeli olan tezlerin verileri araştırma kapsamına dâhil edilememiştir. Ayrıca YÖK Ulusal Tez Merkezi sayfasında yer alan hazırlanmakta olan tezler kısmı bulunmaktadır. Fakat bu bölümün aktif olarak güncellenmediği anlaşılmıştır. Örneğin, geçmiş yıllarda tamamlanmış bazı tezler halen hazırlanmakta olan tezler bölümünde yer alırken hazırlanan tezlerin bu alanda yer almadığı tespit edilmiştir.

Tez kapsamında incelemesi yapılan bazı tezlerde yapılan istatistiksel işlemlerin sonucunda elde edilen bulguların uygun şekilde rapor edilmediği görülmüştür. Örneğin, birçok tezde MannWhitney U Testi yapılmış, deney ve kontrol gruplarına ilişkin aritmetik ortalama ve standart sapma verilmediğinden istatistiksel incelemenin yapılamaması sebebiyle meta analize dâhil edilememiştir. İncelenen tezlerde deney ve kontrol gruplarına ilişkin birçok demografik bilgi toplandığı görülmüştür. Okul öncesi eğitim alıp almama durumu, ebeveynlerin çalışma ve öğrenim düzeyleri gibi veriler sadece çalışma grubuna ilişkin betimsel istatistikler olarak raporlandığı tespit edilmiştir. 
Deney grubundaki eğitimsel müdahalelerin bu demografik veriler ile karşılaştırmasının rapor edilmediği anlaşılmaktadır.

Okul öncesi dönem yaş grubunda yer alan çocukların gelişimlerini destekleyen eğitimsel müdahaleleri içeren 246 adet lisansüstü tez olduğu belirlenmiştir. 6282 deney ve 6195 kontrol grubu olmak üzere toplamda 12477 kişilik bir örneklem büyüklüğüne ulaşılan 246 bireysel çalışmanın puanlarının rastgele etkiler modeline göre yapılan birleştirme işlemi sonucunda, müdahale grubu lehine 1,102'lik pozitif ve istatistiksel olarak anlamlı bir etki büyüklügü bulunmuştur. Yapılan homojenlik testleri (Q ve I2) sonucunda yüksek düzeyde hetorojenlik bulunmuştur. Rastgele etkiler modelinde ortaya çıkan 1,102'lik değer büyük etki büyüklüğü ya da çok büyük düzeyde etki büyüklüğü olarak kabul edilmektedir.

Moderatör analizleri sonucunda eğitimin toplam süresi, her bir oturumun süresi ve uygulamanın yapıldığı yaş grubuna ait etki büyüklükleri arasında anlamlı farklılık saptanmazken müdahalelerin toplam haftası, haftalık oturum sayısı ve uygulama yapılan gruptaki çocuk sayısı ile ilgili analizlerde anlamlı farklılık saptanmıştır. Buna göre, eğitim süresi 10 hafta ve üzerinde olan, haftada üç gün üzerinde eğitim uygulanan ve uygulama yapılan gruptaki çocuk sayısı 20'nin altında olan uygulamaların daha etkili olduğu tespit edilmiştir.

Araştırma kapsamına alınan 250 tezden 37'si deney grubundaki çocukların herhangi bir gelişim alanında cinsiyet değişkeni ile ilgili karşılaştırma yaptığı tespit edilmiştir. Cinsiyet değişkeninin ele alındığı 37 çalışmanın etki büyüklükleri homojen yapıda olduğu ve sabit etkiler modeline göre değerlendirilmesi gerektiği sonucuna ulaşılmıştır. Sabit etkiler modeline göre yapılan değerlendirmede uygulanan eğitimsel müdahalenin kız çocukları ile erkek çocukları arasında gelişimsel olarak farklılığa neden olmadığı tespit edilmiştir.

\section{Öneriler}

Araştırmadan elde edilen bulgular sonucunda şu öneriler geliştirilmiştir.

- Araştırmanın temel veri kaynağı olan lisansüstü tezlere erişim konusunda yazarlar tarafından erişim engeli konulmaktadır. YÖK Ulusal Tez Merkezi, araştırmacıları tezlerinin herkes tarafından erişilebilir olması konusunda özendirebilir.

- Tez kapsamında yapılan istatistiksel işlemlerin sonuçları raporlanırken Mann-Whitney U Testi, Kruskal Wallis-H Testi, t testi ve F testi sonuçları ile birlikte örneklem büyüklügü, aritmetik ortalama ve standart sapma değerlerinin de verilmesine özen gösterilmesi önerilmektedir. 
- Araştırma kapsamina giren fakat YÖK Ulusal Tez Merkezi'nde erişim engeli olduğu için analize dâhil edilemeyen tezlere ulaşmak için künye kısmında yazar e-posta bilgisinin yer alması önerilmektedir.

- YÖK Ulusal Tez Merkezi, web sayfasında bir süredir hazırlanmakta olan tezler için bir alan ayırmıştır. Ancak hazırlanan tezler ile ilgili bu alanda güncellemeler sağliklı bir şekilde yapılmamaktadır. Eğer bu alan sürekli olarak güncellenirse ileride yapılacak olan meta analiz çalışmalarında analizi yapılmış ancak raporlaştırma aşamasına gelmiş olan çalışmalar meta analize dâhil edilmiş olur. Bu açıdan YÖK Ulusal Tez Merkezi hazırlanmakta olan tezler sayfası sık sık güncellenmelidir.

- Araştırma kapsamında incelenen 250 lisansüstü tezde ele alınan anne yaşı, anne öğrenim düzeyi, baba yaşı, baba öğrenim düzeyi, okul öncesi eğitim alıp almama durumu, kardeş varlığı ve doğum sırası gibi değişkenlere yönelik yeterli veri olmamasından kaynaklı meta analiz incelemesi yapılamamıştır. Araştırmalarda anlamlı sonuçlar çıkmasa dahi bu tür değişkenlere ilişkin verilerin rapor edilmesi, ilerleyen yıllarda meta analiz için veri doygunluğunun sağlanmasına katkı sağlayacağından araştırmacıların araştırmalarının doğasına uygun olan değişkenlerin karşılaştırmalarını içeren analiz sonuçlarını raporlamaları önerilmektedir.

- Araştırma kapsamında Türkiye'deki lisansüstü tezlerdeki uygulanan eğitimsel müdahale programlarının okul öncesi dönem çocuklarının gelişimlerine ortalama etkisi ortaya konmuştur. Bundan sonra yapılacak araştırmalarda veri doygunluğuna ulaşan her bir gelişim alanı (bilişsel, psikomotor, sosyal duygusal, dil gelişimi) ile ilgili daha detaylı incelemeler yapılabilir. Örneğin, bilişsel gelişim alanında okul öncesi dönem çocuklarının problem çözme becerilerine ya da yaratıcı düşünme becerilerine yönelik çalışmaların meta analizi gibi çalışmalar yürütülebilir.

- Bu araştırmanın okul öncesi dönem çocuğu olan ebeveynlere, alanda çalışan öğretmen ve akademisyenlere rehber niteliğinde olduğu düşünülmektedir. Araştırma kapsamında incelenen her bir tezin etki büyüklüğü orman grafiğinde verilmiştir. Bu grafiklere ilişkin bilgi makalenin sonunda araştırmacının notu kısmında verilmiştir. Ebeveyn ve öğretmenler yüksek etki büyüklüğüne sahip tezlere ulaşıp orada uygulanan eğitimsel uygulamaları kendi çocukları ile ya da sınıflarında uygulayabilirler. Alanda çalışan akademisyenlere ise yeni bir çalışma planlarken düşük ve yüksek etki büyüklügüne sahip tezleri inceleyip kendi çalışmalarını ona göre tasarlamaları önerilmektedir. 
- Yapılan moderatör analizi sonucunda toplam eğitim süresinin 10 hafta ve üzerinde olması, haftalık oturum sayısının haftada üç gün ve üzerinde olması ve uygulama yapılan gruptaki çocuk sayısının 20'nin altında olması önerilmektedir.

- Bu araştırmada lisansüstü tezlerde uygulanan eğitimsel müdahalelerin okul öncesi dönem çocukların gelişimlerine etkisi incelenmiştir. Başka bir araştırmada uygulanan eğitimsel müdahalelerin etkisinin kalıcı olup olmadığının incelenmesi önerilmektedir.

\section{Kaynaklar}

Ahi, B., \& Kildan, A. (2013). An overview of postgraduate thesis within the field of pre-school education in Turkey (2002-2011). Mehmet Akif Ersoy Üniversitesi Eğitim Fakültesi Dergisi, 1(27), 23-46.

Altun, D., Şendil, Ç. Ö., \& Şahin İ. T. (2011). Investigating the national dissertation and thesis database in the field of early childhood education in Turkey. Procedia Social and Behavioral Sciences, 12, 483-492.

Alvarez-Bueno, C., Hillman, C. H., Cavero-Redondo, I., Sánchez-López, M., Pozuelo-Carrascosa, D. P., \& Martínez-Vizcaíno, V. (2020) Aerobic fitness and academic achievement: A systematic review and meta-analysis. Journal of Sports Sciences, 38(5), 582-589.

Alvarez-Bueno, C., Pesce, C., Cavero-Redondo I,. Sanchez-Lopez, M., Garrido-Miguel, M., \& Martínez-Vizcaíno, V. (2017). Academic achievement and physical activity: A meta-analysis. Pediatrics, 140(6), 1-14.

Avar, G., \& Ilıcan, S. (2018). Okul öncesi fen eğitimi alanında Türkiye'de yapılan lisansüstü tezlerin incelenmesi (2013-2017). Akademik Sosyal Araştırmalar Dergisi, 6(71), 1-16.

Bertan, M., Haznedaroğlu, D., Koln, P., Yurdakök, K., \& Güçiz, B. D. (2009). Ülkemizde erken çocukluk gelişimine ilişkin yapılan çalışmaların derlenmesi (2000-2007). Çocuk Să̆lĭ̆ı ve Hastalıkları Dergisi, 52, 1-8.

Borenstein, M., Hedges, L., Higgins, J., \& Rothstein, H. (2013). Meta analize giriş. (S. Dinçer, Çev.). Ankara: Anı.

Bowne, J. B., Magnuson, K. A,. Schindler, H. S., Duncan, G. J., \& Yoshikawa, H. (2017). A metaanalysis of class sizes and ratios in early childhood education programs: are thresholds of quality associated with greater impacts on cognitive, achievement, and socioemotional outcomes? Educational Evaluation and Policy Analysis, 39(3), 407- 428.

Can-Yaşar, M., \& Aral, N. (2011). Türkiye'de okul öncesinde drama alanında yapılan lisansüstü tezlerin incelenmesi. Mehmet Akif Ersoy Üniversitesi Ĕ̆itim Fakültesi Dergisi, 11(22), 70-90. 
Card, N. A. (2012). Applied meta-analysis for social science research. (T. D. Little, Ed.). New York: The Guilford.

Cohen, J. (1988). Set correlation and contingency tables. Applied Psychological Measurement, 12(4), 425434.

Cho, S. J. (2004). Effects of interventions to enhance social interactions between children with special needs and their peers: A Meta-Analysis. (Doctoral Dissertation). ProQuest Dissertations and Theses database. (UMI No. 3120799).

Cooper, H., Hedges, L. V., \& Valentine, J. C. (2019). The handbook of research synthesis and meta-analysis. New York: Russell Sage Foundation.

Corcoran, R. P., O'Flaherty, J., Xie, C., \& Cheung, A. C. (2020). Conceptualizing and measuring social and emotional learning: A systematic review and meta-analysis of moral reasoning and academic ability, religiosity, political orientation, personality. Educational Research Review, 30, 100285. https://doi.org/10.1016/j.edurev.2019.100285

Cumming, G. (2012). Understanding the new statistics. New York: Routledge, Taylor, and Francis Group.

De Greeff, J. W., Bosker, R. J., Oosterlaan, J., Visscher, C., \& Hartman. E. (2018). Effects of physical activity on executive functions, attention, and academic performance in preadolescent children: a meta-analysis. Journal of Science and Medicine in Sport, 21, 501-507.

Duval, S., \& Tweedie, R. (2000). Trim and fill: a simple funnel plot-based method of testing and adjusting for publication bias in meta-analysis. Biometrics, 56(2), 455-463.

Elliott, S. G., Patricia, T., Shauna, M. B., \& Albert, V. C. (2013) Effectiveness of physical activity interventions for preschoolers: a meta-analysis. Research Quarterly for Exercise and Sport, 84(3), 287-294.

Engel, A. C., Broderic C. R., van Doorn N., Hardy L. L., \& Parmenter, B. J. (2018). Exploring the relationship between fundamental motor skill interventions and physical activity levels in children: A systematic review and meta-analysis. Sports Medicine, 48, 1845-1857.

Ertürk-Kara, H. G., \& Aydın-Şengül, Ö. (2016). Türkiye'de okul öncesi dönemde fen eğitimi alanındaki çalışmaların incelenmesi. Uluslararası Aile Çocuk ve Ĕ̆itim Dergisi, 8, 61-85.

Fukking, R., Jiling, L., \& Oostdam, R. (2017). A meta-analysis of the impact of early childhood interventions on the development of children in the Netherlands: an inconvenient truth? European Early Childhood Education Research Journal, 25(5), 656-666.

Gözüyeşil, E., \& Dikici, A. (2014). Beyin temelli öğrenmenin akademik başarıya etkisi: bir meta analiz çalışması. Kuram ve Uygulamada Ĕ̆gitim Bilimleri Dergisi, 14(2), 1-20. 
Günindi, Y., Aydın, F., Ertürk-Kara, H. G., \& Koruk, H. (2018). Erken çocukluk dönemine yönelik sosyal beceri alanında yapılan çalışmaların incelenmesi. 27. Uluslararası Eğitim Bilimleri Kongresi Özet Bildiri Kitabı. Ankara: Pegem Akademi.

Heckman, J. (2012). Invest in early childhood development: Reduce deficits, strengthen the economy. https://heckmanequation.org/assets/2013/07/F HeckmanDeficitPieceCUSTOMGeneric 052714-3-1.pdf sayfasından erişilmiştir.

Hunt, M. (1997). How science takes stock: The story of meta-analysis. Newyork: Russel Sage Foundation.

Johnstone, A., Hughes, A. R., Martin, A., \& Reilly, J. J. (2018). Utilizing active play interventions to promote physical activity and improve fundamental movement skills in children: a systematic review and meta-analysis. BMC Public Health, 18, 1-12. https://doi.org/10.1186/s12889-018$\underline{5687 \mathrm{z}}$

Kasser, T. A. (2016). Effects of behavior supports on math intervention outcomes: A meta-analysis. (Master's thesis). https://escholarship.org/uc/item/1p0255dw sayfasından erişilmiştir.

Kennedy, A. S. (2010). A meta-analysis of interventions to improve social competence in early childhood. (Doctoral Dissertation). https://ecommons.luc.edu/cgi/viewcontent.cgi?article=1112\&context= luc diss sayfasından erişilmiştir.

Kim, S. (2018). Pretend play and language development among preschool children: A meta-analysis. (Master's thesis). $\quad$ https://krex.k-state.edu/dspace/bitstream/handle/2097/38859/SoominKim2018.pdf? sequence $=1 \&$ isAllowed $=y$ sayfasından erişilmiştir.

Kwon, H., Lee, E., \& Lee, D. (2016). A meta-analysis on the effectiveness of invention education in South Korea: Creativity, attitude, and the tendency for problem-solving. Journal of Baltic Science Education, 15(1), 48-57.

Milli Eğitim Bakanlığı. (2013). Milli Eğitim Bakanlığı Temel Eğitim Genel Müdürlüğü Okul Öncesi Eğitim Programı. Ankara.

Murano, D. M. (2019). Improving measurement and expanding meta-analytic knowledge: Social and emotional learning in elementary and early childhood. (Doctoral Dissertation). https://academicworks.cuny.edu/cgi/viewcontent.cgi?article $=4501 \&$ context $=$ gc etds sayfasından erişilmiştir.

Nelson, G., \& McMaster, K. L. (2019). The effects of early numeracy interventions for students in preschool and early elementary: A meta-analysis. Journal of Educational Psychology, 111(6), 1001-1022.

OECD. (2016). Education at a glance 2016: OECD indicators. Paris: OECD. 
OECD. (2017). Family database. https://stats.oecd.org/Index.aspx?DataSetCode=FAMILY sayfasından erişilmiştir.

Oktay, A. (2007). Yaşamın sihirli yılları: Okul öncesi dönem. İstanbul: Epsilon.

Öncül, N. (2014). Türkiye'de erken çocuklukta özel eğitim ile ilgili yapılmış makalelerin gözden geçirilmesi. International Journal of Early Childhood Special Education (INT-JECSE), 6(2), 247-284.

Petticrew, M., \& Roberts, H. (2006). Systematic reviews in the social sciences: A practical guide. Massachusetts: Blackwell.

Rafe, E. (2006). Dışa yönelim problemleri olan okulöncesi çocukları hedef alan müdahale programlarımın meta analizi ve Türk okulöncesi çocuklara yönelik bir müdahale programı. (Yüksek Lisans Tezi). https://tez.yok.gov.tr sayfasından erişilmiştir.

Schimmel, L. (2018). A meta-analysis of academic \& sociallemotional benefits associated with preschool participation. (Doctoral Dissertation). http://digital.auraria.edu/content/AA/00/00/72/74/00001/ Schimmel ucdenver 0765D 11070.pdf sayfasından erişilmiştir.

Thalheimer, W., \& Cook, S. (2002). How to calculate effect sizes from published research: A simplified methodology. Work-Learning Research, 1, 1-9.

Taştepe, T., Öztürk-Serter, G., Yurdakul, Y., Taygur-Altıntaş, T., \& Bütün-Ayhan, A. (2016). Türkiye'de okul öncesi dönemde kaynaştırma konusunda yapılan lisansüstü tezlerin incelenmesi. The Journal of Academic Social Science Studies, 49, 501-514.

Tavşancıl, E., \& Aslan, E. (2001). Sözel, yazılı ve diğer materyaller için içerik analizi ve uygulama örnekleri. İstanbul: Epsilon.

Turgut, S., \& Doğan-Temur, Ö. (2017). The effect of game-assisted mathematics education on academic achievement in Turkey: a meta-analysis study, International Electronic Journal of Elementary Education, 10(2), 195-206.

Utesch, T., Bardid, F., Büsch, D., \& Strauss, B. (2019). The relationship between motor competence and physical fitness from early childhood to early adulthood: A meta-analysis. Sports Medicine, 49, 541-551.

Van Capelle, A., Broderick, C. R., van Doorn, N., Ward, R. E., \& Parmenter, B. J. (2017). Interventions to improve fundamental motor skills in pre-school aged children: A systematic review and meta-analysis. Journal of Science and Medicine in Sport, 20(7), 658-666.

Vazou, S., Pesce, C., Lakes, K., \& Smiley-Oyen, A. (2019). More than one road leads to Rome: A narrative review and meta-analysis of physical activity intervention effects on cognition in youth, International Journal of Sport and Exercise Psychology, 17(2), 153-178. 
Wick, K., Leeger-Aschmann, C. S., Monn, N. D., Radtke, T., Ott, L., V. Rebholz, C. E., ...., \& Kriemler, S. (2017). Interventions to promote fundamental movement skills in childcare and kindergarten: A systematic review and meta-analysis. Sports Med, 47, 2045-2068.

Yılmaz, E. (2002). Yükseköğretim kurulu dokümantasyon merkezinden ulusal tez merkezine doğru. Türk Kütüphaneciliği, 16(1), 41-60.

Yılmaz, E. (2018). Erken çocukluk döneminde üstün yetenekliler ile ilgili Türkiye'de yapılan çalışmaların incelenmesi. Uluslararası Erken Çocukluk Ĕ̆gitimi Çalışmaları Dergisi, 3(2), 1-16.

Zeng, N., Ayyub, M., Sun, H., Wen, X., Xiang, P., \& Gao, Z. (2017). Effects of physical activity on motor skills and cognitive development in early childhood: a systematic review. BioMed Research International, 2017, 1-13.

\section{Extended Summary}

Preschool years, which form the basis of all development areas of human life, are when the physical, motor, social and emotional, mental, and language development of the child is shaped to a great extent. Various academic studies such as books, articles, papers, thesis, etc., are carried out to develop these fields in our country as in the whole world. It is seen that the studies in the preschool field are carried out for different groups such as parents, children, teachers, teacher candidates, or academicians, as well as planned to include various methods such as experimental, descriptive, relational, and case analysis. It is essential to plan the research prepared for preschool children in an experimental design, determining the interventions that support development areas and spreading them in the field. Besides, meta-analysis studies, in which the applied interventions are handled as a whole, and the effects of the given training on development areas are needed. This study aimed to examine the impact of experimental thesis studies on preschool-age children's development areas using meta-analysis methods published between 1998 and 2020 in Turkey.

The study group of this study, which is planned as a meta-analysis study, consists of the experimentally designed master's and doctoral thesis studies conducted between 1998-2020 (March 15, 2020) to support the development areas of preschool children and published at the National Thesis Center. The data were transferred to the coding table prepared by the researcher. The relevant database has been searched using the keywords "pre-school" and "experiment", "preschool" and "experiment" "kindergarten" and "experiment", "kindergarten" and "experiment", "early childhood" and "experiment" and "early childhood education" and "experiment". Ten randomly selected theses for coding reliability were sent to two academicians working in the preschool field and entered in the coding table separately by these two experts. As a result of the calculation, it was determined that there is a $99 \%$ concordance between the researcher and the first expert and $98 \%$ between the second expert. The reason why a study is not included in the meta-analysis is that it is outside the research's 
limitations or does not have the necessary statistical data for meta-analysis (Card, 2012). Therefore, in this study, qualitative studies, studies published outside the specified years, excluding the sample group "preschool children", studies that do not contain the necessary statistics for meta-analysis and whose access were blocked by the author were excluded from the scope. 250 out of 437 theses, which were examined according to the inclusion and exclusion criteria, were included in the meta-analysis. Comprehensive Meta-Analysis V3.0 (CMA) software trial version was used for data analysis. In the data analysis, to determine the average effect, combinations were made according to fixed effects and random effects model, homogeneity test, funnel chart, and Duval and Tweedie's (2000) Trim and Fill tests were used. The results were interpreted according to "Cohen's d" effect size statistics. Also, metaregression analysis was performed for six variables.

As a result of the research, it was seen that 140 of 250 theses included in meta-analysis contributed to cognitive development, 28 of them contributed to psychomotor development and 97 of them to social-emotional development. The educational interventions in the theses were mostly applied in independent public kindergartens. For the development score results of the theses included in the meta-analysis the average effect size value was calculated as ES $=0.750$, the standard error of the average effect size was $\mathrm{SE}=0.020$, the lower limit of the confidence interval of the mean effect size was 0.711, and the upper limit was 0.788 . According to the random-effects model, the standard error of the theses included in the meta-analysis is SE $=0.070$. The lower limit of the $95 \%$ confidence interval is 0.965, and the upper limit is 1.238 . The common effect size of the theses is ES $=1.102$. The fact that the calculated I2 value is well above $75 \%(\mathrm{I} 2=91,573)$ indicates that the distribution of effect sizes calculated according to the fixed effects model is heterogeneous. Accordingly, the use of the randomeffects model is appropriate. Statistical significance in combinations made according to the randomeffects model was found as $Z=15,816$ when calculated according to the $Z$ test. Therefore, it was determined that the results were in favour of the experimental group because there was a statistically significant difference between the experimental group and the control group $(p<0.001)$, and the common effect size was positive (ES = 1.102) in the evaluation of the development scores. The value of 1.102 obtained as a result of the analysis made in accordance with the random-effects model is considered large effect size in the view of Cohen's (1988) classification, and very high effect size according to the classification of Thalheimer and Cook (2002). As a result of the meta-analysis of 246 postgraduate theses that support preschool children's development, it was concluded that the educational interventions applied in the theses have significant contributions to the development of children $(E S=1,102)$. Six moderator analyses were conducted to explain the heterogeneity of the combined mean effect size of the development. These variables were determined as the entire week of the application, the number of sessions in a week, the number of children in the group where the 
application was made, the total minutes of the application, the duration of each session and the age group in which the application was made. As a result of the analyses, no moderator effect could explain the average effect size heterogeneity in the total minutes, each session's application time and age group variables. A significant difference was found in the moderator analysis of the entire week of educational interventions related to development, the number of weekly sessions, and the number of children in the applied group. It has been determined that the effect size of the theses with ten weeks or more education duration, three days of education per week, and less than 20 children in the group in which the practice is applied, is larger. Besides, it was determined that the fixed effects model should be used according to the homogeneity test results in analyzing the gender variable. According to the fixed effects model, as a result of the analysis of the gender variable, it was determined that there was no statistically significant difference between girls and boys $(p=0.486)$.

As a result of the meta-analysis of 246 graduate theses supporting preschool children's development, it was concluded that the educational interventions applied in the theses contributed significantly to the development of children (ES $=1,102)$. In the study of Schimmel (2018) examining the relationship between participation in preschool education and academic achievement and social/emotional area, it was found that there is no difference in academic success and socialemotional aspects between children who receive preschool education and those who do not. Wick et al. (2017) examined interventions to develop fundamental movement skills in kindergarten. It was found that interventions applied for 4 or 5 weeks in terms of fundamental motor skills had a higher effect size than interventions applied for six weeks or longer. It is recommended that the theses in the national thesis centre should not be restricted and that the statistical analysis should be reported completely in the studies.

\section{Araştırmacıların Katkı Oranı Beyanı}

$\mathrm{Bu}$ araştırmanın planlanması, yürütülmesi ve yazılı hale getirilmesinde yazarlar eşit oranda katkıda bulunmuştur.

\section{Destek ve Teşekkür Beyanı}

$\mathrm{Bu}$ araştırmada herhangi bir kurum, kuruluş ya da kişiden destek alınmamıştır.

\section{Çatışma Beyanı}

Araştırmacıların araştırma ile ilgili diğer kişi ve kurumlarla herhangi bir kişisel ve finansal çıkar çatışması yoktur. 


\section{Etik Kurul Beyanı}

$\mathrm{Bu}$ araştırma, herkesin erişimine açık hazır veriler kullanılarak yapılan meta analiz çalışması olduğundan etik kurul izni gerektirmemektedir.

\section{Araştırmacının Notu}

$\mathrm{Bu}$ çalışmada incelemeye alınan tezlere ve bu tezlere ait etki büyüklüğünü gösteren orman grafiklerine ilişkin ayrıntılı bilgiye ulaşmak isteyen okuyucular yazarlarla iletişime geçebilir. 